\title{
Baltık Kuru Yük Endeksi Etkin mi?
}

\section{Is Baltic Dry Index Efficient?}

\author{
Abdullah ACIK, Dokuz Eylül University, Turkey, abdullah.acik@deu.edu.tr \\ Sadık Ozlen BASER, Dokuz Eylül University, Turkey, ozlen.baser@deu.edu.tr
}

\begin{abstract}
Öz: Etkin piyasa hipotezi (EPH), fiyatların mevcut tüm bilgileri yansittyor olduğunu ve dolaylsılla hiçbir yatırımcının gelecek fiyatları tahmin etmek için bir avantajı olmadlğını öne sürmektedir. EPH'ye göre, satın alma ve satma kararlarının geçmiş verilere dayandığı teknik ticari kurallar, ekonomik açıdan olağanüstü fazla kazançlara neden olmamalıdır. Denizcilik sektörünün etkin piyasa özellikleri göstermesi özellikle küçük yatırımcılar için hayati bir öneme sahiptir,çünkü bu sektör sermaye yoğun bir sektördür. Bu bağlamda, bu çalışmanın amacl, kuru yük piyasasında navlun oranlarının etkin olup olmadığını belirlemektir.Çünkü eğer navlun piyasaları etkinse, alınan kararların kârlllı̆̆a bir etkisi olmayacaktır. Ama eğer etkin değilse, kar olanakları ortaya çıkmaktadır. Navlun piyasasındaki taşımacıllk ücretlerinin göstergesi olarak Baltık Kuru Yük Endeksi (BDI) seçilmiştir. Veriler 4 Ocak 1985 ile 1 Aralık 2017 tarihleri arasını kapsamaktadır. Veri günlük bazda 8264 gözlem içermektedir. Metodoloji, kuru dökme piyasanın verimli olup olmadığını belirlemek için birim kök testi, varyans oranı testi ve Brock, Dechert ve Scheinkman (BDS) bağımsızlık testi olmak üzere 3 ana uygulamadan oluşmaktadır. Bu çalışmanın, yaygın olarak kullanılan yöntemlerle beraber BDS testini de kullanarak etkinliği farklı bir yöntemle test ederek literatüre katkıda bulunacağı düşünülmektedir. Sonuçlar etkin piyasa hipotezinin kuru dökme piyasa için geçerli olmadı̆̆ıı ve piyasada kâr firsatlarının doğduğunu göstermektedir.
\end{abstract}

Anahtar Sözcükler: Baltık Kuru Yük Endeksi, Denizcilik, Etkin Piyasa Hipotezi, BDS Testi

Abstract: The efficient market hypothesis (EMH) suggests that prices fully reflect all available information and thus no investor has any advantage in forecasting future prices. According to EMH, the technical commercial rules -in which sale and purchase decisions are based on historical datashould not result in excess profits. As shipping is a capital intensive industry, it is vital for the maritime industry to have efficient market characteristics, especially for small-sized participants. In this context, the purpose of this study is to determine whether the freight rates are efficient in the dry bulk market. When the freight market is efficient, the decisions that are taken will have no effect on profitability. Whereas, when the market is inefficient, profit opportunities arise. Baltic Dry Index (BDI) is selected as an indicator of transportation service prices in freight market. The data covers the period between 4th January 1985 and 1st December 2017. The data consists of 8264 daily observations. The methodology consists of 3 main applications that are used to measure the efficiency of the dry bulk market. These applications are unit root test, variance ratio test and Brock, Dechert and Scheinkman (BDS) independence test. It is hoped that this study will contribute to literature by testing the efficiency with a different method, using the BDS test, in addition to the commonly used methods. The results indicate that the efficient market hypothesis is not valid for the dry bulk market and profit opportunities still arise in the market.

Keywords: Baltic Dry Index, Maritime, Efficient Market Hypothesis, BDS Test.

\section{Introduction}

Maritime transport is a mode of transport that covers the majority of the world trade. Thus the greatest demand for the transport industry comes from world economic activities, which means freight rates are formed by derived demand. This results in the immediate impact of most economic fluctuations on the maritime industry (Stopford, 2009:136).

The interest in testing Efficient Market Hypothesis (EMH) in the dry bulk market has partially increased during the last decade (Engelen et al, 2009). If the freight rates are considered to be the price of transport services that are unstorable and non-tradeable, traditional EMH form cannot be applied to freight rate pricing. But the concept of EMH can still be applied to freight markets (Adland and Strandenes, 2006).

According to $\mathrm{EMH}$, prices, as all possible information are reflected at any given time, no investor can earn extraordinary profits. Because no one has the opportunity to acquire any information that is not available for everyone (Fama, 1970). The efficient market hypothesis consists of 3 forms; (1) if current prices of an asset reflects all information in the past prices it is called weak form; (2) if it reflects all publicly available information it is called semistrong form; (3) if it reflects all public and private information it is called strong form. Current prices of an asset incorporates with these forms (Adland and Strandenes, 2006).

According to EMH in weak form, the current prices include all the information from past prices. This means that no investor can earn much profit by establishing models based on historical prices. Because prices will move randomly according to the weak form of EMH. According to the semi-strong form of EMH, prices include all publicly available information as well as all historical data. Hence no investor can make excess profit above the average using public information. The semi-strong EMH says that current prices already include all of the publicly available information. Lastly, prices based on EMH in strong form include all information, including non-printed information. This also includes insider information and views of the company's managers. So no investor can make excess profit above the average using printed or non-printed information (Ogilvie, 2005).

According to EMH, the technical commercial rules which purchase and sale decisions are based on historical data should not result in an economically remarkable excess profits (Adland and Koekebakker, 2004). 
Two models that support the Efficient Market Hypothesis are named as the random walk model and the martingale model (Ogilvie, 2005:97). According to the random walk theory, there is no memory of price changes. Historical prices cannot be used to predict future values (Fama, 1965). Tomorrow's price is independent of today's price (Ogilvie, 2005:65). The other model is the martingale model. According to this model, if the market is efficient, the current prices contain all the available information. So in the absence of new information, the price of tomorrow is equal to today's price. Moreover, according to the martingale model, asset prices are unpredictable (Karakitsos, 2014:104). If a market is martingale, it means it is efficient and if the price of an asset follows random walk, it can be said that it is efficient in weak form.

More precisely, if the information in a market is distributed to all participants and prices remain unaffected, it can be said that the market is efficient. It is necessary for the market to exhibit perfect competition characteristics and its participants must to be completely rational to obey efficient market property (Karakitsos et al. 2014:100). Global bulk freight market is a very illustrative example of the perfect competition market, it offers homogenous and fungible transport services with a large number of suppliers and consumers (Stopford 2009:180).

When testing the efficient market hypothesis, economists focus on whether excess profits are zero or not in two alternative market strategies in freight markets. These strategies are time charter and spot charter strategies. If excess profit is 0 , it can be said that the market is efficient, but if the excess profit is not 0 , the market is inefficient (Karakitsos et al. 2014). As mentioned by Adland and Strandenes (2006), traditional form of EMH cannot be applied to freight rate pricing process, but the notion of EMH still applies to the freight market. Consequently, Baltic Dry Index is selected as an indicator of transportation service prices in freight market. It covers dry bulk shipping rates and provides an assessment of the price of moving the major raw materials by sea. The index consists of 26 shipping routes measured in time charter and voyage basis (Geman, 2008:181). Since its establishment, the BDI has become one of the primary indicators on the cost of shipping and an important barometer on the volume of worldwide trade and manufacturing activity (Lin and Sim, 2013).

In this context, the purpose of this study is to determine whether the freight rates are efficient in the dry bulk market. Because if the freight markets are efficient, the decision that is taken will make no difference in profitability. Otherwise, if the market inefficient, profit opportunities arises.

In the next part of the study, similar works in the literature are discussed. Afterwards, the methods of the research are introduced and the results of the analyzes are presented.

\section{Literature Review}

Although the literature is rich in terms of efficient market hypothesis, the study of this hypothesis in terms of maritime market is limited. As noted by Adland and Strandenes (2006), traditional form of efficient market hypothesis doesn't apply to freight market because rates cannot be stored or traded. But still, the reflection of the EMH occurs in the freight market.

Studies have mainly examined the freight markets and second hand markets in the maritime literature. This may be due to the price fluctuations in the shipbuilding industry responding late to economic activity and the scrap prices being directly affected by the steel demand. According to Lun et al. (2013:16), entrance of a new vessel to the market may take one to three years. Merikas (2015) investigates the relationship between the steel industry and scrap prices and found that the ship demolition market is one of the main supplier of steel industry. Moreover, according to Grammenos (2010), freight rates and second hand prices tend to move together in a cyclical trend. This indicates that the efficiency level in freight markets will also have a direct impact on the sale and purchase market. Thus, the studies in the literature are concentrated in areas outside shipbuilding and demolition industries. They are concentrated in the freight market, sale and purchase market and the forward freight agreement (FFA) market.

When the studies on the maritime literature are reviewed, a very limited number of studies has been reached. In order to understand the position of this study in the related literature, it would be useful to classify the prior studies in two groups. The first group consists of studies in the sale and purchase market. A study implemented by Adland and Koekebakker (2004) investigates the validity of the EMH in the second-hand market for bulk ships. They find that trading rules in this market doesn't offer chance for producing excess profit over buy and hold benchmark. The results of the paper support the validity of EMH in the second-hand market for bulk ships. But the authors have also found that some markets in the lower segments are not efficient. Another study carried out by Alizadeh and Nomikos (2007) measure the performance of trading strategies based on some technical trade rules in the sale and purchase market for dry bulk ships. The authors find evidence that these strategies exhibit outperformance as a result of this work. According to these results, it can be said that there is no clear view in the sale and purchase market.

The second group consists of studies in the freight market. Tsioumas and Papadimitriou (2015) have analyzed the trip charter rates and the corresponding time charter rates by technical rules to develop trading strategies, and they have discovered that it is possible to make profit by these strategies. Because trip charter rates are more comprehensive in terms of the information they receive. Time charter rates, on the other hand, are more insensitive to new information because of contractual restrictions and promises. In other words, the result of the research shows that the efficient market hypothesis is not valid. Adland and Strandenes (2006) investigate whether a tanker's owner could achieve a profitable position based on past spot prices. They analyze the historical data with technical methods and test the profitability of the chartering strategies. The results show that owners of large tanker fleets can make big profits without 
investing in a new ship by only using this information trade. The conclusion of this study is that the efficient market hypothesis is not valid in the freight market. Nomikos and Doctor (2013) have used quantitative trading methods in the Forward Freight Agreement (FFA) market and as a result they have shown that the rules of trade outperform the buyand-hold benchmark.

According to EMH, the application of the technical trade rules should not permanently result in an economically significant excess of profits where purchase and sale decisions are based on past price patterns (Adland and Koekebakker, 2004). When the limited studies in the literature are examined, it can be seen that excessive profit can be obtained when strategies are developed according to past price patterns in both freight and sale and purchase markets. As this study examines the freight market, the sole focus is on efficiency of freight markets. Inefficiency in freight markets would make it possible to profit consistently and extensively by using trading strategies. Even though the efficiency in the freight market which is the main focus of this study, has already been studied, unlike previous studies, the EMH is examined in this study using the BDS test, a rarely used method in efficiency measurements, and the findings are compared to the results of previous studies. Accordingly, this study contributes in a different way to EMH analysis of maritime literature and intends to form a complementary structure to previous studies. The next section introduces the methods that are used for measuring the efficient market hypothesis in dry bulk freight market.

\section{Methodology}

The methodology consists of three main application which are "unit root test", "variance ratio test" and "BDS independence test" to determine whether the dry bulk market efficient or not. Eviews 10, which is a commonly used econometric software, was used in the analyses.

The first method used in the research, unit root test, is a widely used and relatively older method. According to Hassan et al. (2007), unit root test can be used for testing the efficiency of the markets, because a market necessitates randomness to be defined as efficient. Unit root tests investigate whether the time series is stationary or not. If the market is efficient, it should include unit root and should be non-stationary. The Augmented Dickey-Fuller test, one of the most common tests used in this field, was selected and used for the determination of order of integration (Dickey and Fuller, 1979). The null hypothesis of this test suggests that the series include unit roots and if the series contain unit roots, it indicates that this market is efficient in weak form.

Variance test statistics which was introduced by Lo and MacKinlay (1989) were used to test random walk. It examines the predictability of time series data by comparing variances of differences of the data calculated over different intervals. The variance ratio test is used to examine whether the series is martingale. If the series is martingale, it denotes its efficiency. The null hypothesis of this test suggests that the series is martingale. Chow and Denning (1993) proposed multiple variance ratio test which is similar to variance ratio test. The only difference is variance ratio test provides individual results of each interval while multiple variance ratio test provides the joint probability. Both the variance ratio and the multiple variance ratio tests used in this study.

Next method for efficiency test is the Brock, Dechert and Scheinkman (BDS) statistic proposed by Brock et al. (1987). BDS test is a method used to examine time-based dependency in a series. This test can be applied to residuals of an estimated model. The null hypothesis of this test is that data in a time series is independently and identically distributed (Brock et al, 1996). In other words if there is a dependency between residual values, null hypothesis is rejected which means the residuals contain some hidden, possibly non-linear, structure and consequently the market is not efficient.

\subsection{Data}

The data covers the period between 4th January 1985 and 1st December 2017. The data consists of 8264 daily observations. The data was obtained from the Bloomberg Data Platform. The Baltic Dry Index series is converted to a series of log returns using the formula below (1).

$$
R_{B D I}=\ln \left(B D I_{t}\right)-\ln \left(B D I_{t-1}\right)
$$

where;

$\mathrm{BDI}_{\mathrm{t}}$ is closing value of the related index on day $\mathrm{t}$

$\mathrm{BDI}_{\mathrm{t}-1}$ is closing value of the related index on day $\mathrm{t}-1$

Graphical representations of the normal and log return series are presented in Figure 1. The economic boom in 2008 and the subsequent collapse can be clearly seen. Since it is a derived demand, maritime transport is directly affected by these developments in the world economy. Also it is obvious that the lack of efficiency in shipping will provide substantial advantages to some information holders. 

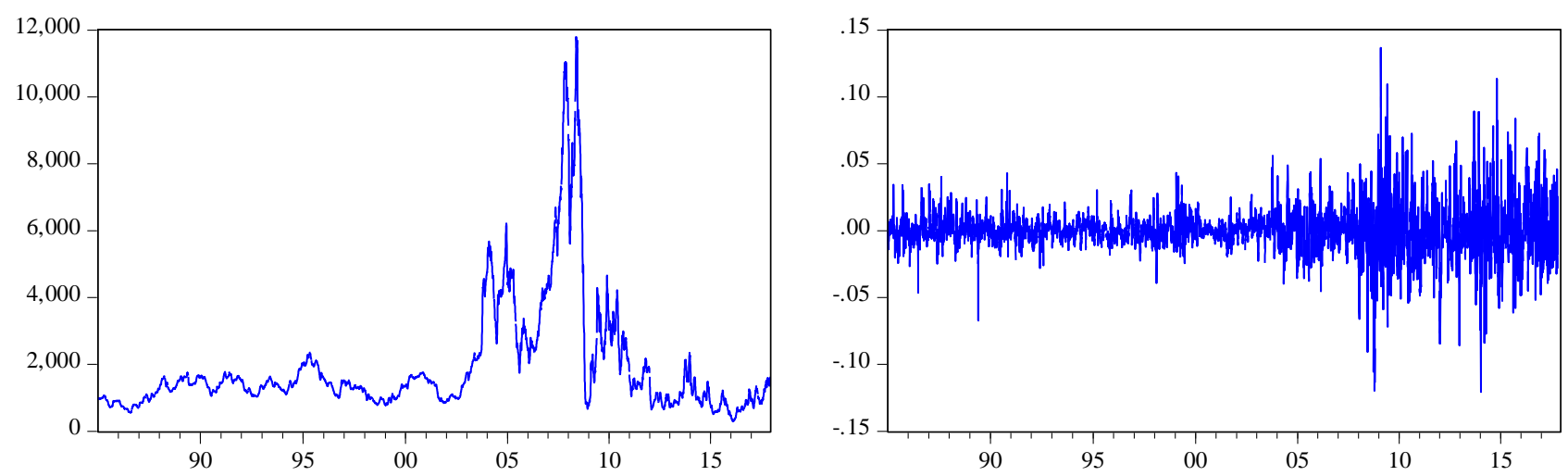

Figure 1. Baltic Dry Index and Its Log Return Series Source: Bloomberg Data Platform

The descriptive statistics of the data for the Baltic Dry Index are shown in Table 1. According to the pure database, the average of the 33 year-data collected from the 8264 observations is 1908 points. The highest score was 11.793 pounds reached in 2008 and the lowest score was 290 points reached in 2016.

Table 1. Descriptive Statistics of Baltic Dry Index

\begin{tabular}{|c|c|c|c|}
\hline & BDI & Log Return BDI & Residuals \\
\hline Observations & 8264 & 8263 & 8263 \\
\hline Mean & 1908.894 & $5.88 \mathrm{E}-05$ & $2.67 \mathrm{E}-07$ \\
\hline Median & 1378.500 & 0.000000 & -0.000120 \\
\hline Maximum & 11793.00 & 0.136576 & 0.100599 \\
\hline Minimum & 290.0000 & -0.120718 & -0.093589 \\
\hline Std. Dev. & 1695.172 & 0.015341 & 0.009490 \\
\hline Skewness & 2.900114 & 0.125931 & 0.096307 \\
\hline Kurtosis & 12.60678 & 11.69851 & 16.46332 \\
\hline Jarque-Bera & 43362.87 & 26072.36 & 62419.46 \\
\hline Probability & 0.000000 & 0.000000 & 0.000000 \\
\hline
\end{tabular}

\section{Analysis and Results}

Three different analyzes were performed on the data; namely, the unit root test, the variance ratio test and the BDS independence test as mentioned in the methodology section. The results of these analyses are presented in the following sections respectively.

\subsection{Unit Root Test for Market Efficiency}

Unit root test is one of the tools that measures the weak form market efficiency. The results of the Augmented DickeyFuller test are shown below. The null hypothesis of this test implies that the series contains unit root. As shown in Table 2 , the probability value is less than the critical value of 0.05 which denotes that the null hypothesis is rejected. The result is that the series is stationary and does not follow random walk. This suggests that the series is not efficient in weak form.

Table 2. Augmented Unit Root Test Results

\begin{tabular}{|c|r|c|c|}
\hline \multicolumn{2}{|c|}{} & Intercept & Trend and Intercept \\
\hline \multicolumn{2}{|c|}{ Level } & & \\
\hline \multicolumn{2}{|c|}{ BDI } & $-28.41538 * * *$ & $-28.41407 * * *$ \\
\hline \multirow{2}{*}{$\begin{array}{c}\text { Critical } \\
\text { Values }\end{array}$} & $1 \%$ & -3.430965 & -3.959147 \\
\cline { 2 - 4 } & $5 \%$ & -2.861696 & -3.410347 \\
\cline { 2 - 4 } & $10 \%$ & -2.566895 & -3.126926 \\
\hline
\end{tabular}




\subsection{Variance Ratio Test for Market Efficiency}

The variance ratio test is used to examine whether the series is martingale. If the series is martingale, it denotes its efficiency. The null hypothesis of this test suggests that the series is martingale. The results of the test are shown in Table 3 and the null hypothesis is rejected according to the probabilities of joint tests and individual tests. As a result, this test also confirms that the Baltic Dry Index is not efficient in the weak form.

Table 3. Variance Ratio Test Results

\begin{tabular}{|c|c|c|c|c|}
\hline \multicolumn{2}{|c|}{ Joint Tests } & Value & $d f$ & Probability \\
\hline \multicolumn{2}{|c|}{ Max |z| (at period 8) } & 7.761263 & 8262 & 0.0000 \\
\hline \multicolumn{2}{|c|}{ Individual Tests } & & & \\
\hline Period & Var. Ratio & Std. Error & $z$-Statistic & Probability \\
\hline 2 & 1.017635 & 0.027442 & 0.642635 & 0.5205 \\
\hline 4 & 0.787989 & 0.047662 & -4.448195 & 0.0000 \\
\hline 8 & 0.464343 & 0.069017 & -7.761263 & 0.0000 \\
\hline 16 & 0.265224 & 0.094972 & -7.736726 & 0.0000 \\
\hline
\end{tabular}

\subsection{BDS Independence Test for Market Efficiency}

The ARMA model is established and the return series is tried to be purified from its deterministic elements. Furthermore, in this way, the variance used in the analysis is minimized and the consistency of the analysis is increased. After the model is estimated, the residues are extracted from the model and subjected to the BDS independence test as mentioned in the method section. The automatic ARIMA forecast function in the econometric software was used for this process and the most suitable model was determined according to the Akaike criteria. Maximum AR and maximum MA values were selected as 12 per each. Maximum differentiation option was selected as 0 , because the log return series is already stationary as seen in Table 2. ARMA $(11,12)$ model with AIC value of -6.473 was chosen as the most suitable model. Akaike criteria scores of top 20 ARMA models are shown in Figure 2.

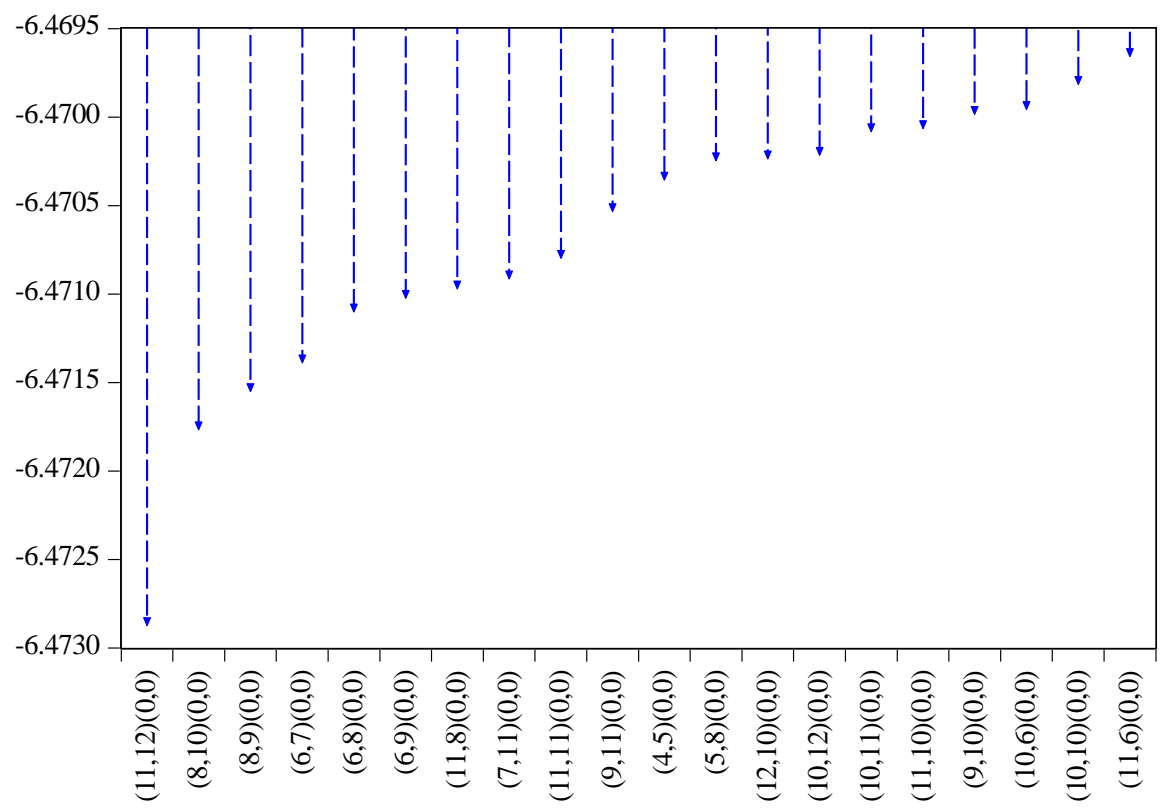

Figure 2. Top 20 ARMA Models Based on Their Akaike Information Criterias

After determining the most appropriate ARMA model, it is switched to the estimation stage. The most important points to be checked after the ARMA model is estimated are that the F test of the model should be significant and that both AR and MA roots should be smaller than 1. As shown in Table 3 below, the probability of the F test of the model is smaller than the critical value, and both the AR and MA roots are smaller than 1. 
Acik, A., Baser, S., O. / Journal of Yasar University, 2018, 13/50, 140-149

Table 3. Estimation Results of ARMA $(11,12)$ Model

\begin{tabular}{|c|c|c|c|c|}
\hline \multicolumn{5}{|c|}{ Dependent Variable: Log Return BDI } \\
\hline Variable & Coefficient & Std. Error & t-Statistic & Prob. \\
\hline $\mathrm{C}$ & $7.18 \mathrm{E}-05$ & 0.000471 & 0.152534 & 0.8788 \\
\hline $\operatorname{AR}(1)$ & 2.090405 & 0.037532 & 55.69728 & 0.0000 \\
\hline $\mathrm{AR}(2)$ & -2.385924 & 0.066281 & -35.99712 & 0.0000 \\
\hline $\mathrm{AR}(3)$ & 1.695572 & 0.063947 & 26.51507 & 0.0000 \\
\hline $\mathrm{AR}(4)$ & -0.651707 & 0.034469 & -18.90686 & 0.0000 \\
\hline $\mathrm{AR}(5)$ & 0.419017 & 0.014606 & 28.68702 & 0.0000 \\
\hline $\mathrm{AR}(6)$ & -0.372885 & 0.013528 & -27.56472 & 0.0000 \\
\hline $\operatorname{AR}(7)$ & 1.097646 & 0.013658 & 80.36671 & 0.0000 \\
\hline $\mathrm{AR}(8)$ & -2.137097 & 0.037303 & -57.29055 & 0.0000 \\
\hline $\mathrm{AR}(9)$ & 2.370216 & 0.062837 & 37.72031 & 0.0000 \\
\hline $\operatorname{AR}(10)$ & -1.605540 & 0.064920 & -24.73123 & 0.0000 \\
\hline $\operatorname{AR}(11)$ & 0.419606 & 0.030001 & 13.98641 & 0.0000 \\
\hline $\mathrm{MA}(1)$ & -1.200774 & 0.038228 & -31.41125 & 0.0000 \\
\hline $\mathrm{MA}(2)$ & 1.148480 & 0.037946 & 30.26619 & 0.0000 \\
\hline $\mathrm{MA}(3)$ & -0.477420 & 0.031394 & -15.20749 & 0.0000 \\
\hline MA(4) & 0.088298 & 0.015482 & 5.703334 & 0.0000 \\
\hline MA(5) & -0.342479 & 0.015123 & -22.64588 & 0.0000 \\
\hline MA(6) & 0.130787 & 0.011850 & 11.03653 & 0.0000 \\
\hline MA(7) & -0.951595 & 0.012416 & -76.64159 & 0.0000 \\
\hline $\mathrm{MA}(8)$ & 1.277763 & 0.033070 & 38.63804 & 0.0000 \\
\hline MA(9) & -1.068748 & 0.037083 & -28.82055 & 0.0000 \\
\hline MA(10) & 0.445404 & 0.031993 & 13.92182 & 0.0000 \\
\hline MA(11) & 0.118506 & 0.011962 & 9.906478 & 0.0000 \\
\hline MA(12) & 0.095941 & 0.010701 & 8.965421 & 0.0000 \\
\hline SIGMASQ & $9.00 \mathrm{E}-05$ & $5.48 \mathrm{E}-07$ & 164.2672 & 0.0000 \\
\hline$R$-squared & 0.617353 & $F$-statistic & & 553.7910 \\
\hline Adjusted $R$-squared & 0.616238 & Prob(F-stati & & 0.000000 \\
\hline Inverted AR Roots & $.95+.11 \mathrm{i}$ & $.95-.11 \mathrm{i}$ & $.55+.78 \mathrm{i}$ & $.55-.78 \mathrm{i}$ \\
\hline & .51 & $.42+.90 \mathrm{i}$ & $.42-.90 \mathrm{i}$ & $-.25+.97 i$ \\
\hline & $-.25-.97 i$ & $-.89-.45 \mathrm{i}$ & $-.89+.45 \mathrm{i}$ & \\
\hline Inverted MA Roots & $.93+.13 \mathrm{i}$ & $.93-.13 \mathrm{i}$ & $.56+.79 \mathrm{i}$ & $.56-.79 \mathrm{i}$ \\
\hline & $.43-.90 \mathrm{i}$ & $.43+.90 \mathrm{i}$ & $-.18+.29 \mathrm{i}$ & $-.18-.29 \mathrm{i}$ \\
\hline & $-.25+.97 i$ & $-.25-.97 \mathrm{i}$ & $-.89-.46 \mathrm{i}$ & $-.89+.46 \mathrm{i}$ \\
\hline
\end{tabular}

The use of ARMA in the model is to separate the deterministic elements from the model. As mentioned in the methodology section, the BDS test is applied to the residuals of the series. So the next step is to extract the residuals from the model. The descriptive statistics of residuals can be seen in Table 1. According to Jarque-Bera (1982) statistics, the fact that residuals do not conform to the normal distribution can also be interpreted as an ineffectiveness indicator for the market. The graphical representation of the residuals is also presented in Figure 1. This chart also shows the regimes formed during the historical process in the market. Excessive fluctuations after 2008 show the magnitude of the impact of the global crisis. 


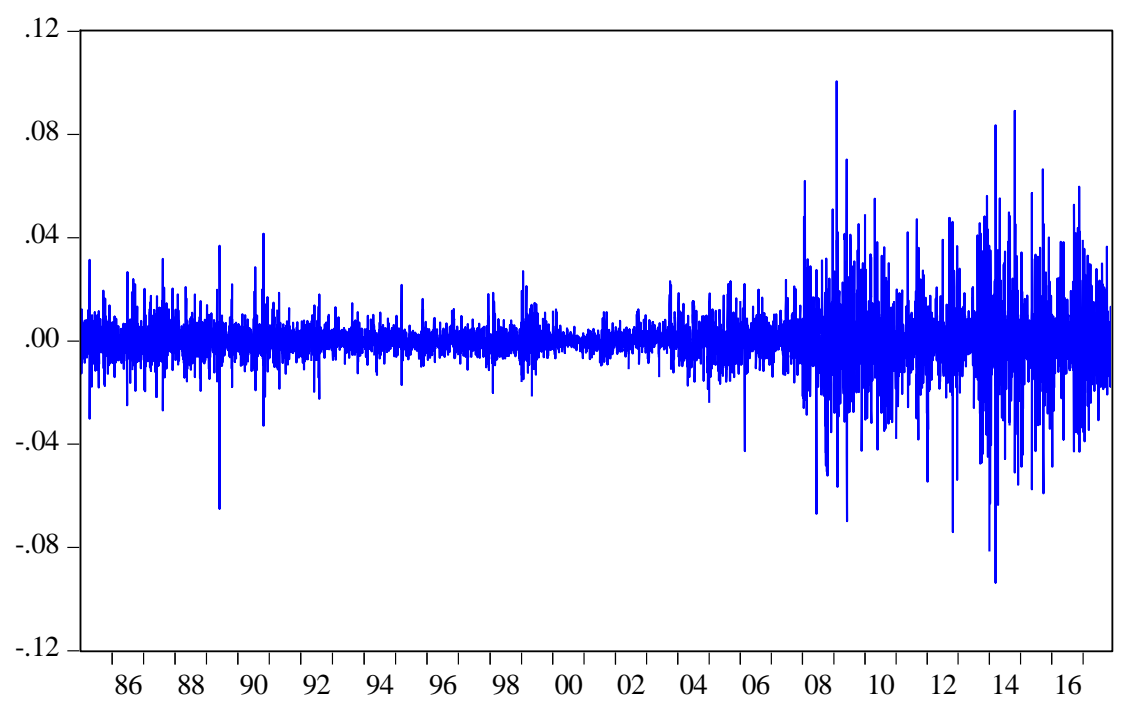

Figure 3. Residuals of the ARMA Model

Attachment 1 shows the AC (autocorrelation) and PAC (partial autocorrelation) tables of residual values obtained from the model. This table, regardless of the BDS test, allows us to get a preview of whether there is memory on the series. The null hypothesis of this test is that there is no autocorrelation. When the results are examined, it is seen that the null hypothesis can not be rejected from the 1st delay to the 104th delay which means that there is no memory in the series until the 105th lag. But after this point, it is seen that the null hypothesis is rejected in all lags after the 105 th lag. This indicates that there is a long-run memory in the series. This memory can also be interpreted as an indicator that this market is inefficient. The next step is to apply the BDS independence test to the residuals to confirm these results.

As mentioned before, the BDS test can be applied to the estimated residuals to check whether the residuals are independent and identically distributed. The null hypothesis of this test assumes that the series is distributed independently and identically. The results of the test are presented in Table 4, and the null hypothesis for all dimensions is rejected according to the results. The implication is that the residuals contain some hidden, possibly non-linear, structure. In other words, past data contains information for future values, which means that market efficiency in weak form is rejected.

Table 4. BDS Independence Test Results

\begin{tabular}{|c|c|c|c|c|}
\hline Dimension & BDS Statistic & Std. Error & $z$-Statistic & Prob. \\
\hline 2 & 0.052883 & 0.001265 & 41.82078 & 0.0000 \\
\hline 3 & 0.101135 & 0.002011 & 50.29249 & 0.0000 \\
\hline 4 & 0.136058 & 0.002397 & 56.75314 & 0.0000 \\
\hline 5 & 0.158883 & 0.002502 & 63.49737 & 0.0000 \\
\hline 6 & 0.171503 & 0.002417 & 70.96286 & 0.0000 \\
\hline
\end{tabular}

\section{Conclusion and Discussion}

This study aims to contribute to the current limited literature on efficiency of freight markets by using BDS test which is a different method that is rarely used for market efficiency researches. In addition, unit root test and variance ratio test were used to verify the results. Baltic Dry Index is selected as an indicator of transportation service prices in the freight market. BDI covers dry bulk shipping rates and provides an assessment of the price of moving the major raw materials by sea and it consists of 26 shipping routes measured in time charter and voyage basis (Geman, 2008:181). BDI has become one of the primary indicators on the cost of shipping and an important barometer on the volume of worldwide trade and manufacturing activity (Lin and Sim, 2013).

Series was converted to return series, and unit root test and variance ratio test were applied to this return series. For the BDS test, the deterministic elements were estimated using ARMA model and residuals were extracted from the model, as the BDS method is applied to residuals (Brock et al, 1996).

According to the results of all the tests performed, it was determined that BDI did not present random walk or martingale characteristics which are seen as fundamental indicators of being an efficient market (Ogilvie, 2005:97). This situation does not comply with the effecient market definition of Fama (1965), and as Adland and Koekebakker 
(2004) point out, technical and commercial rules can lead to excess profits in this freight market. These findings suggest that the freight rates do not follow a random walk which implies that the market is not efficient in the weak form.

The results, which show inefficiency in the freight market, are consistent with the previous studies in the literature that apply different techniques. Efficiency in sale and purchase market was investigated by Adland and Koekebakker (2004) and Alizadeh and Nomikos (2007), and they have found that sale and purchase market is inefficient. As Grammenos (2010) points, the freight market and the sale and purchase market cycle together. This means, as the inefficiency in this market would indicate inefficiency in the freight market, the findings of this study are mostly consistent with these findings about sale and purchase market. Efficiency of freight market was examined by Tsioumas and Papadimitriou (2015), Adland and Strandenes (2006) and Nomikos and Doctor (2013), and the authors found that freight market also demonstrates inefficient market characteristics. The results of these studies related to the freight market are consistent with our work as well. This study examines the efficient market hypothesis with the BDS independence test, a rarely used method and contributes existing literature.

The dry bulk market meets almost perfect competition market conditions (Stradenes, 2012:115). Since there are many carriers and shippers, a large number of transport transactions are being carried out. Therefore, while the information flow is limited, the information capacities and effects on the market are very high for those with high bargaining power in the market. These players with high bargaining power do not look for information sharing, as information sharing will benefit the interests of very small-sized players rather than their own interests. This is one of the most important factors that trigger the market ineffectiveness.

At this point, researchers should focus on increasing the effectiveness of the market by examining how this information, which has not been transmitted, can be made more accessible on the market. With this way, it will be possible to prevent unusual profits which is obtained in inefficient markets by using past information and hiding information. In addition, the manipulation opportunities of the market can also be prevented.

All these developments will contribute to the elimination of competitive disadvantages of stakeholders resulting from inefficiency of freight markets. In addition, a fair market environment will be provided to prevent the creation of extra costs, resulting in a cost-saving effect reaching the end-users.

The biggest limitation of this work is data availability. BDI, which is a combination of spot and time charter prices, is used as representative of freight rates. However, clearer and more precise results could be obtained by allocating spot and time charter prices. In addition, further studies can investigate the efficiency of the other maritime markets such as tanker, container and gas markets. 


\section{REFERENCES}

Alizadeh, A. H., and N. K. Nomikos. 2007. "Investment Timing and Trading Strategies in the Sale and Purchase Market for Ships." Transportation Research Part B: Methodological 41 (1): 126-143.

Bera, A. K. and Jarque, C. M. 1982 "Model Specification Tests: A Simultaneous Approach.” Journal of Econometrics, 20: 59-82.

Bloomberg Data Platform, Baltic Dry Index, Accessed 02.12.2017

Brock, W. A., Dechert, W. D. and Scheinkman, J. A. 1987. "A test for independence based on the correlation dimension.” Manuscript, Social Systems Research Unit, University of Wisconsin.

Brock, William, Davis Dechert, Jose Sheinkman and Blake LeBaron. 1996. "A Test for Independence Based on the Correlation Dimension.” Econometric Reviews 15(3): 197-235.

Chow, K. V. and Denning, K. C. 1993. “A Simple Multiple Variance Ratio Test.” Journal of Econometrics 58: 385401.

Dickey, D. A. and Fuller, W. A. 1979. "Distribution Of The Estimators For Autoregressive Time Series With A Unit Root." Journal of the American Statistical Association 74: 427-431.

Fama, E. 1970. "Efficient Capital Markets: A Review of Theory and Empirical Work." Journal of Finance 25: $383-417$.

Geman, H. (Ed.). 2009. Risk Management in Commodity Markets: From shipping to agriculturals and energy (Vol. 445). John Wiley \& Sons.

Grammenos, C. T. 2010. The Handbook of Maritime Economics \& Business, London: Informa.

Hassan, A., M. Shoaib and Shah. 2007. "Testing of Random Walk and Market Efficiency In an Emerging Market: An Empirical Analysis of KSE.” Business Review Cambridge 271-281.

Karakitsos, E., \& Varnavides, L. 2014. Maritime Economics: A Macroeconomic Approach. Springer.

Lin, F., \& Sim, N. C. 2013. "Trade, İncome and The Baltic Dry Index.” European Economic Review 59: 1-18.

Lo, Andrew W. and A. Craig MacKinlay. 1989. "The Size and Power of the Variance Ratio Test in Finite Samples." Journal of Econometrics, 40: 203-238.

Lun, V., Hilmola, P. 2013. Oil Transport Management. London: Springer-Verlag

Merikas, A., Merika, A., \& Sharma, A. 2015, January. "Exploring Price Formation in the Global Ship Demolition Market." In 2015 Annual Meetings.

Nomikos, N., and K. Doctor. 2013. "Market Timing Strategies in the Freight Derivatives Market." Transportation Research Part E: Logistics and Transportation Review 52: 77-93.

Ogilvie, J. and Parkinson, C. 2005. Management Accounting - Financial Strategy. Great Britain: Elsevier

Roar Adland \& Siri Strandenes. 2006. "Market Efficiency in The Bulk Freight Market Revisited." Maritime Policy \& Management: The flagship journal of international shipping and port research 33(2): 107-117

Roar Adland \& Steen Koekebakker. 2004. "Market Efficiency in the Second-hand Market for Bulk Ships." Maritime Economics \& Logistics 6: 1-15.

Steve Engelen, Wout Dullaert \& Bert Vernimmen. 2009. "Market Efficiency Within Dry Bulk Markets in The Short Run: A Multi-Agent System Dynamics Nash Equilibrium.” Maritime Policy \& Management: The flagship journal of international shipping and port research 36(5): 385-396.

Stopford, M. 2009. Maritime economics 3e. Routledge.

Strandenes, S. P. (2012). "Maritime Freight Markets". The Blackwell Companion to Maritime Economics, $11,107$.

Tsioumas, V., and S. Papadimitriou. 2015. "Excess Returns in the Spot Market for Bulk Carriers.” Maritime Economics \& Logistics 17: 399-415 
Attachment 1- AC (autocorrelation) and PAC (partial correlation) Test Results

\begin{tabular}{|c|c|c|c|c|c|c|c|c|c|c|c|c|c|c|}
\hline $\mathrm{L}$ & $\mathrm{C}$ & $\mathrm{AC}$ & -Stat & Prob & $\mathrm{L}$ & $\mathrm{C}$ & PAC & Q-Stat & 100 & $\mathrm{~L}$ & $\mathrm{AC}$ & PAC & Q-Stat & 1100 \\
\hline 1 & .000 & .000 & .0004 & 984 & 51 & 0.017 & 0.017 & 40.433 & 0.856 & 101 & 0.010 & 0.009 & 118.64 & 111 \\
\hline 2 & 0.001 & .001 & 0047 & 998 & 52 & -0.008 & -0.009 & 0.906 & .866 & 102 & .008 & .009 & 19.12 & 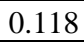 \\
\hline 3 & & & & & 53 & & -0.027 & 6.402 & 727 & 103 & .014 & 013 & 20.73 & 112 \\
\hline 4 & 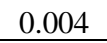 & 0004 & & 996 & 54 & & & & & 104 & & & & \\
\hline 5 & & & & & 55 & & -0.018 & 51.368 & & 105 & & & & 42 \\
\hline 6 & -0.00 & -0.007 & & 997 & 56 & -0.002 & -0.001 & 51.410 & & 106 & 0.000 & 0.002 & 1.22 & \\
\hline 7 & & & & & 57 & 0006 & -0.003 & 1.669 & & 107 & -0012 & & & \\
\hline 8 & 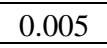 & 0.005 & & 999 & 58 & 0.001 & 0.002 & 51.678 & & 108 & 0.020 & & & .036 \\
\hline 9 & 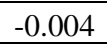 & 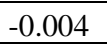 & & 000 & 59 & 006 & 007 & 1.931 & & 109 & -0.002 & & & 042 \\
\hline 10 & 0.00 & 0.009 & & 999 & 60 & 0.003 & 0.003 & 2.020 & & 110 & 0.000 & -0.001 & & 048 \\
\hline 11 & & 02 & & 999 & 61 & & & 2.341 & & 111 & & & & \\
\hline 12 & & 006 & & 999 & 62 & 0.024 & 0.022 & 56.955 & & 112 & 0.012 & & 7.81 & 049 \\
\hline 13 & & 007 & & 99 & 63 & م & -0.009 & 57.301 & & 113 & .000 & & .81 & 056 \\
\hline 11 & & & & & 64 & & & & & 114 & & & & \\
\hline- & -0 & -0007 & & & 65 & & & & & 115 & & & & \\
\hline 16 & & -1 & & 84 & 66 & & & & & 116 & & & & \\
\hline- & & 0 & & & 67 & & & & & 117 & & & & \\
\hline & & & & & 68 & & & & & 118 & & & & \\
\hline 19 & & 0.008 & & 91 & 69 & & & 71 & & 119 & & & 8.78 & 33 \\
\hline 2 & & & & & 70 & & & & & 120 & & & & \\
\hline 21 & & 03 & & 97 & 71 & & & 7 & & 121 & & & & 228 \\
\hline & & & & & 72 & & & & & 122 & & & & \\
\hline 2. & & 006 & & & 73 & & & & & 123 & & & & \\
\hline 2 & & & & & 74 & & & & & 122 & & & & \\
\hline 2 & & & & & 75 & & & & & 125 & & & & \\
\hline 26 & & & & & 76 & & & & & 126 & & & & \\
\hline 2 & -0 & -( & & & 77 & & & & & 127 & & & & \\
\hline 2 & & & & & 78 & & & & & 128 & & & & \\
\hline 29 & & & & & 79 & & & & & 129 & & & & 06 \\
\hline 30 & & & & & 80 & & & & & 130 & & & & \\
\hline 31 & & & & & 81 & & & & & 131 & & & & \\
\hline 32 & & & & & 82 & & & & & 132 & & & & \\
\hline ( & & & & & 83 & & & & & 133 & & & & \\
\hline 34 & & & & & 84 & & & & & 134 & & & & \\
\hline & & & & & 85 & & & & & 135 & & & & \\
\hline 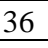 & & & & & 86 & & & & & 136 & & & & \\
\hline - & & & & & & & & & & 13 & & & & \\
\hline 38 & & & & & 88 & & & & & 138 & & & & \\
\hline 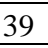 & & & & & 89 & & & & & 139 & & & & \\
\hline 40 & -0. & -0 & & & 90 & & & 3 & 50 & 140 & & & 31 & 03 \\
\hline - & & & & & 91 & & & & & 141 & & & & \\
\hline 42 & -0 . & & & & 92 & & & & 6 & 142 & & & 85 & 03 \\
\hline 43 & & & & & 93 & & & & & 143 & & & & \\
\hline 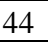 & & & & & 94 & & & & & 144 & & & & \\
\hline 45 & & & & & 95 & & & & & 145 & & & & 0.004 \\
\hline 46 & -0.006 & & & & 96 & & & & & 146 & & & & \\
\hline 47 & & & & & 97 & & & & & 147 & & & 4.33 & 0.005 \\
\hline 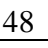 & & & & & 98 & & & & & 148 & & & & 0.006 \\
\hline 49 & & & & & 99 & & & & & 149 & & & 195.41 & 0.006 \\
\hline 50 & $00 t$ & 006 & 7003 & 95 & 10 & & & 117 & & 150 & & & 96.17 & 0.007 \\
\hline
\end{tabular}

